\title{
Undergraduate Students' Academic Information and Help-Seeking Behaviours using an Anonymous Facebook Confessions Page (Paper)
}

\author{
Richard Hayman \\ Associate Professor \& Digital Initiatives Librarian \\ Library, Mount Royal University \\ rhayman@mtroyal.ca
}

Erika E. Smith

Assistant Professor \& Faculty Developer

Academic Development Centre, Mount Royal University

eesmith@mtroyal.ca

\author{
Hannah Storrs \\ Undergraduate Psychology Student \& Research Assistant \\ Mount Royal University \\ hstor460@mtroyal.ca
}

\begin{abstract}
This research examines undergraduate students' academic help-seeking behaviours by mining anonymous posts from a university Facebook Confessions page. From a dataset of 2,712 public posts, researchers identified 708 Confessions (26.1\%) that supported student-student learning exchanges. Using a mixed methods methodology informed by a social constructivist framework, analysis of these social media interactions demonstrates that students use Confessions posts to legitimately inform their undergraduate learning and support their academic experience. Researchers conclude that Facebook Confessions can enable rich academic help-seeking and other information behaviours, and that these sites should be taken seriously by administrators, faculty, researchers, and students.

\section{Purpose}

This mixed methods research examines a Facebook Confessions page at a Canadian undergraduate university to explore the evolving and diverse nature of anonymous, online students help-seeking and information sharing behaviours using social media. The research addresses the following research questions: (RQ1) Do undergraduates use their university Facebook Confessions page for help-seeking to support their post-secondary learning experiences? If so, (RQ2) what is the nature of these interactions, and what post-secondary teaching or learning considerations may they reveal?
\end{abstract}

\section{Relevant Literature}


The use of Facebook among university students continues to raise complex issues for those teaching, researching, and supporting post-secondary education. Social media tools and technologies are blurring the boundaries between personal and academic educational interactions (Jones, Blackey, Fitzgibbon, \& Chew, 2010; Smith, 2016). The rise of anonymous Facebook Confessions pages at many higher education institutions (Budryk, 2013) draws a diversity of post-secondary students to publicly, but anonymously, share their perspectives, opinions, and questions about a wide variety of topics with the world. Several researchers have examined issues of relationships, sex, and cyberbullying on Facebook Confessions pages generally (e.g. Barari, 2016; Houlihan \& Houlihan, 2014; Dominguez-Whitehead, Whitehead, \& Bowman, 2017). Amador and Amador (2014) presented their case study for the use of Facebook to support academic advising, while Clark-Gordon, Workman, and Linvill (2017) highlighted that anonymous information seeking and sharing behaviours do occur frequently among students using other social media platforms. However, none of the existing research has examined whether post-secondary students use their anonymous Facebook Confessions pages for academic purposes, particularly for online help-seeking and other information behaviours that inform their university learning experience.

\section{Research Design \& Data Collection}

This study used exploratory mixed methods research (MMR) as an overarching methodology, under which qualitative and quantitative data collection and analysis was conducted (Creswell \& Plano Clark, 2018). Social constructivism guided this research, a framework where the participants' perceptions, meanings, and views are the focus. Within learning theory, social constructivists view knowledge to be constructed via social negotiation that engages multiple perspectives and experiences (Driscoll, 2005; Woolfolk, Winne, Perry, \& Shapka, 2010). Within research on educational technologies, alignment between the affordances of social media and the premises of social constructivism are established (Dron \& Anderson, 2014). This study uses definitions of help and information seeking (Thomas, Tewell, \& Willson, 2017) in congruence with established digital literacy frameworks, since Bawden (2008) notes that abilities to leverage "people networks" as sources of information, help, and advice, are a key part of developing digital literacy (p. 20).

Researchers used the Facebook Graph API to collect a dataset of 2,712 confessions posted publicly and anonymously to a Canadian, undergraduate-focused university's Facebook Confessions page during one academic year (July 2016 to June 2017). Data mining captured the content of each confession (i.e., text of the original post), date and time of posting, any reactions (i.e., likes and shares), and a hyperlink for each post to ensure any comments or replies were easily accessible. Researchers independently analyzed each post, and using intercoder strategies they developed and applied inclusion criteria to include only confessions with an explicit help-seeking or other information behaviour of an academic nature (e.g., questions about programs, courses, grades, studying, etc.). Posts lacking an academic or educational topic, such as social or personal interactions (e.g., relationships, parties, etc.), were excluded.

Using generic qualitative strategies (Merriam \& Tisdell, 2015) researchers performed a content analysis informed by constructivist grounded theory (Charmaz, 2014) and discourse analysis 
techniques (Potter, 2008; Gee, 2014). Researchers analyzed all included confessions to identify emerging themes by applying specific, descriptive coding reflecting the language that students themselves used in their confessions. Capturing both descriptive and process elements, researchers used intercoder strategies via a consensus model (Saldana, 2016) to ensure consistency and maintain rigour when assigning codes. The quantitative analysis focused on primarily on descriptive data, including percentage and frequency, to track whether specific topics or themes emerge at certain times of year.

\section{Findings}

Of the 2,712 total original confessions, 708 (26.1\%) met the inclusion criteria. Regarding RQ1, the analysis of 709 confessions confirmed that undergraduate students use the Confessions page to support their university learning. Researchers readily identified numerous academic help-seeking and other learning-related information behaviours despite the non-academic nature of the Confessions page. Addressing RQ2, researchers identified several instances of students exchanging theoretical, practical, and academic information specifically related to their undergraduate education. These topics were wide-ranging and varied, and included information queries related to university (e.g., "Are there any credit online courses? If so where?"), help seeking for course recommendations (e.g., "Is [course code] a difficult course? Opinions anyone?'), and genuine cries for help in dealing with the demands and pressures of student life (e.g., "I'm feeling extremely overwhelmed with everything. It's my first year and I need help but I don't know where to go and what to do about it. Anyone able to suggest where I can go?'). Further qualitative analysis identified several core teaching and learning themes emerging from the confessions, including help-seeking for: academic standing and performance; administrative and technology processes; student identity and emotion; university transitioning; courses and studying; programs and degrees; and, tuition and finances. Researchers also discovered a range of information behaviours within the process coding, from offering help to providing unsolicited advice or warnings, and students using their Confessions posts to comment on or moderate other students' behaviours.

\section{Conclusions \& Significance}

This research shows that alongside rumours, cyberbullying, and other social networking behaviours that students already experience using Facebook generally, these undergraduate students used their Confessions page for legitimate academic help-seeking and other information behaviours to inform their university studies. Compared to previous Facebook research, such as Selwyn's (2009) finding that only 4\% of Facebook posts reflected academic aspects of university learning, the nature and frequency of student help-seeking related to post-secondary teaching and learning revealed in this study suggests that Facebook Confessions pages like this should be taken seriously by higher education administrators, faculty, researchers, and students alike. Understanding the ways students use these Confessions for undergraduate help-seeking and online learning behaviours has implications for both research and practice, especially when the anonymous forum can be connected to a specific institution. The full presentation will include discussion of these impacts, as well as the broader questions raised when conducting a qualitatively-driven mixed methods study using larger social media datasets. 


\section{References}

Amador, P., \& Amador, J. (2014). Academic advising via Facebook: Examining student help seeking. Internet and Higher Education, 21, 9-16. https://doi.org/10.1016/j.iheduc.2013.10.003

Barari, S. (2016). Analyzing latent topics in student confessions communities on Facebook. Retrieved from https://arxiv.org/abs/1506.05193

Bawden, D. (2008). Origins and concepts of digital literacy. In C. Lankshear \& M. Knobel (Eds.), Digital literacies: Concepts, policies \& practices (pp. 17-32). New York, NY: Peter Lang Publishing, Inc.

Budryk, Z. (2013, Feb 26). College 'confession' and 'makeout' pages raise privacy, anonymity issues. Inside Higher Education. Retrieved from https://www.insidehighered.com/news/2013/02/26/college-confession-and-makeout-page s-raise-privacy-anonymity-issues

Charmaz, K. (2014). Constructing grounded theory (2nd ed.). Los Angeles, CA: Sage.

Clark-Gordon, C. V., Workman, K. E., \& Linvill, D. L. (2017). College students and Yik Yak: An exploratory mixed-methods study. Social Media + Society, 3(2), 1-11. https://doi.org/10.1177/2056305117715696

Creswell, J. W., \& Plano Clark, V. L. (2018). Designing and conducting mixed methods research ( $3^{\text {rd }}$ ed.). Los Angeles, CA: Sage.

Dominguez-Whitehead, Y., Whitehead, K. A., \& Bowman, B. (2017). Confessing sex in online student communities. Discourse, Context \& Media, 20, 20-32. https://doi.org/10.1016/j.dcm.2017.05.002

Driscoll, M. (2005). Psychology of learning for instruction (3rd. ed.). Boston, MA: Pearson Education, Inc.

Dron, J., \& Anderson, T. (2014). Teaching crowds: Learning and social media. Retrieved from https://doi.org/10.15215/aupress/9781927356807.01

Gee, J. P. (2014). An introduction to discourse analysis: Theory and method (4 ${ }^{\text {th }}$ ed.). New York, NY: Routledge.

Houlihan, D., \& Houlihan, M. (2014). Adolescents and the social media: The coming storm. Journal of Child and Adolescent Behavior, 2(2), e105. https://doi.org/10.4172/2375-4494.1000e105

Jones, N., Blackey, H., Fitzgibbon, K., \& Chew, E. (2010). Get out of MySpace! Computers \& Education, 54(3), 776-782. https://doi.org/10.1016/j.compedu.2009.07.008

Merriam, S. B., \& Tisdell, E. J. (2015). Qualitative research: A guide to design and implementation. San Francisco, CA: John Wiley \& Sons.

Potter, J. (2008). Discourse analysis. In L. M. Given (Ed.), The SAGE encyclopedia of qualitative research methods (pp. 218-220). https://doi.org/10.4135/9781412963909.n113

Saldana, J. (2016). The coding manual for qualitative researchers (3rd ed.). Los Angeles, CA: Sage.

Smith, E. E. (2016). "A real double-edged sword:" Undergraduate perceptions of social media in their learning. Computers \& Education, 103, 44-58.

https://doi.org/10.1016/j.compedu.2016.09.009 
Selwyn, N. (2009). Faceworking: Exploring students' education-related use of Facebook. Learning, Media and Technology, 34(2), 157-174. https://doi.org/10.1080/17439880902923622

Thomas, S., Tewell, E., \& Willson, G. (2017). Where students start and what they do when they get stuck: A qualitative inquiry into academic information-seeking and help-seeking practices. Journal of Academic Librarianship, 43(2), 224-231. https://doi.org/10.1016/j.acalib.2017.02.016

Woolfolk, A. E., Winne, P. H., Perry, N. E., \& Shapka, J. (2010). Educational psychology (4th ed.). Toronto, ON: Pearson Canada. 